\title{
UNCHANGING RULES IN CHANGING TIMES: THE CANONS OF ETHICS AND INTRA-FIRM CONFLICTS OF INTEREST
}

WHEN an attorney represents a client whose interests are antagonistic to past or current clients, serious questions of professional ethics arise. The American Bar Association Canons of Ethics posit the principle that an attorney cannot serve two competing masters, and provide that an attorney must disqualify himself from representing clients in any matter where, broadly speaking, confidences given to an attorney by one client might conceivably be used by the attorney against that client in representing another. ${ }^{1}$ The disqualification does not extend to the lawyer's representation of his client generally, but only to representation in matters in which interests of a client and another past or current client are in fact opposed. ${ }^{2}$ The standards governing

1. The two most applicable Canons, in relevant part, provide as follows: Canon 6. Adverse Influences and Conflicting Interests.

.... It is unprofessional to represent conflicting interests, except by express consent of all concerned given after a full disclosure of the facts. Within the meaning of this canon, a lawyer represents conflicting interests when, in behalf of one client, it is his duty to contend for that which duty to another client requires him to oppose.

The obligation to represent the client with undivided fidelity and not to divulge his secrets or confidences forbids also the subsequent acceptance of retainers or employment from others in matters adversely affecting any interest of the client. with respect to which confidence has been reposed.

Canon 37. Confidences of a Client.

It is the duty of a lawyer to preserve his client's confidences. This duty outlasts the lawyer's employment, and extends as well to his employees; and neither of them should accept employment which involves or may involve the disclosure or use of these confidences, either for the private advantage of the lawyer or his employees or to the disadvantage of the client, without his knowledge and consent, and even though there are other available sources of such information. A lawyer should not continue employment when he discovers that this obligation prevents the performance of his full duty to his former or to his new client. . .

Also involved is Canon 36, which provides, in part:

A lawyer, having once held public office or having been in the public employ, should not after his retirement accept employment in connection with any matter which he has investigated or passed upon while in such office or employ.

The Canons are given the force of statutory law in many jurisdictions. E.g., S.D.N.Y. General Rule 5(c), 16 Fed. Rules Serv. 908 (1952). Cf. Cal. Bus. \& Prof. Code §§ 6068(e), 6076, Rules 5 \& 7. But see Hunter v. Troup, 315 I1l. 293, 302, 146 N.E. 321, 324 (1924).

2. The most widely cited test is that of Judge Weinfeld.

[T] he former client need show no more than that the matters embraced within the pending suit wherein his former attorney appears on behalf of his adversary are substantially related to the matters or cause of action wherein the attorney previously represented him, the former client. The Court will assume that during the course of the former representation confidences were disclosed to the attorney 
the occasions for such individual disqualifications, although harsh, ${ }^{3}$ have been given some flexibility and are, indeed, sometimes uncertain. ${ }^{4}$ By contrast, if it is once ascertained that any one member of a law firm is disqualified, the Canons have been interpreted ${ }^{5}$ to extend, clearly and inflexibly, to include in their prohibition all lawyers associated with him in the firm ; ${ }^{6}$ neither he, his associates, ${ }^{7}$ nor the firm may represent the client in the matter in question. The effect of the interpretation is to engraft upon the Canons the words "or his associates" whenever the term "lawyer" appears. Yet, this injunction against representation by the firm of a disqualified attorney seems often to be ignored in connection with members returning from government serv-

bearing on the subject matter of the representation. It will not inquire into their nature and extent....

[T] he Court must [only] ask whether it can be reasonably said that in the course of the former representation the attorney might have acquired information related to the subject of his subsequent representation. If so, then the relationship between the two matters is sufficiently close to bring the latter representation within the prohibition of Canon 6.

T.C. Theater Corp. v. Warner Bros. Pictures, Inc., 113 F. Supp. 265, $268-69$ (S.D.N.Y. 1953).

3. Id. And see Note, Disqualification of Attorneys for Representing Interests Adverse to Former Clicnts, 64 Y ALE L.J. 917, 918-21 (1955). See generally, Kaplan, Forbidden Retainters, 31 N.Y.U. L. REv. 914 (1956) [hereinafter referred to as Kaplan].

4. See Note, 64 Y ALE L.J. 917, 928 (1955).

5. Responsibility for authoritative interpretation of the Canons is given to ethics committees of the various bar associations as well as to the courts. See DrINKER, LEGAL ETHICs 26-30 (1953) [hereinafter cited as DrInkrR]; and cf., e.g., OpINIONs of The Committees on Professtonal Ethics of the Association of the Bar of the City of New York and the New York County Lawyers' Association (Cromwell Ed. 1956) [hereinafter cited as N.Y. City Bar Op. No. ..., N.Y. County Bar Op. No. ...].

An eight member committee of the American Bar Association is charged with the periodic responsibility of formulating and publishing interpretations of the ABA Canons. See DrInker at 30-32. The opinions have been published in book form. See ANERICAN Bar Ass'n, Opinions of the Committee on Professional Ethics and Grievances (1957) [hereinafter cited as A.B.A. Op. No. ...].

6. W. E. Bassett Co. v. H. C. Cook Co., 201 F. Supp. 821 (D. Conn.), aff'd per curian, 302 F.2d 268 (2d Cir. 1962) (prior confidence given one firm member held bar to current representation of adverse position by other member); Laskey Bros., Inc. v. Warner Bros. Pictures, Inc., 130 F. Supp. 514, 519 n.5 (S.D.N.Y.), aff'd, 224 F.2d 824, 826-27 (2d Cir. 1955) ; United States v. Standard Oil Co., 136 F. Supp. 345, 360 (S.D.N.Y. 1955) ; Weidlich v. Weidlich, 147 Conn. 160, 157 A.2d 910 (1960) (simultaneous representation of adverse interests in civil case by members of the same firm barred) ; Mutual Service Cas. Ins. Co. v. Overholser, 239 Minn. 243, 58 N.W.2d 268 (1953) (same: costs denied on appeal because one firm member represented the plaintiff and another the defendant in accident suit) ; Green v. State, 241 Ind. 96, 168 N.E.2d 345 (1960) (members of same firm represented defendant and the state in a criminal proceeding); Fitzsimmons v. State, 116 Neb. 440, 218 N.W. 83 (1928) (same: conviction reversed); In re Ridgely, 48 Del. 464, 106 A.2d 527 (1954) (Assistant Attorney General allowed by law to conduct private practice not permitted to oppose his firm in a criminal proceeding). See also DRINKER at 106; Kaplan at 926.

7. The law has been held to cover all attorneys within a firm, not only its partners. Consolidated Theaters, Inc. v. Warner Bros. Circuit Management Corp.: In re Proceedings to Disqualify Robert E. Nickerson, 216 F.2d 920, 927 (2d Cir. 1954); DrunkER at 106. 
ice ${ }^{8}$ while the individual lawyer will abstain from work touching upon his government responsibilities, ${ }^{9}$ his firm continues to accept these matters. And, despite the clarity of the injunction, it appears that law firms act in violation of the rule in matters involving wholly private parties as well. ${ }^{10}$ The purpose of this Note is to explore the reasons for the disparity between the broad rule derived from the Canons and the ordinary practice among practitioners, and to suggest a possible resolution of the opposing values at stake.

The dominant purpose of the individual disqualification rule is to preserve the confidential character of the relationship between attorney and client. ${ }^{11}$ Those who argue for a broad disqualification rule state that the relationship can be safeguarded only if the client is altogether certain that his attorney will not use his confidences against him. Thus, it is reasoned, an attorney must be disqualified from representing interests adverse to a client not only where actual confidences have been made by one party which can be used against him, but also where such might appear to be the case to the public at large, the class of present and future clients. ${ }^{12}$ Broad individual disqualification is thus justified in order to avoid even the "appearance of evil."13

Blanket disqualification of the law firm to which a disqualified attorney belongs springs from the same policy roots. The American Bar Association Committee on Professional Ethics and Grievances has explained the rule:

$[T]$ he relations of partners in a law firm are so close that the firm, and all members thereof are barred from accepting any employment that one member of the firm is prohibited from taking. ... . [A] nything which requires a lawyer to withdraw from a case requires that his partners withdraw. ${ }^{14}$

This view is supported by the substantial administrative difficulty of discovering and proving actual breaches of confidence within the close-knit and often informal structure of a law-firm. A heavy burden would rest on a present or former client if he were required to show that his protectable confidences had been passed about within the firm now opposing his interests. ${ }^{15}$ Given the

8. See note 63 infra and accompanying text.

9. See the Federal Conflict of Interest Act, 76 Stat. 1123 (1962), 18 U.S.C. \$§ 207 (a) \& (b) (Supp. IV, 1963), and see text at notes 34-37 infra.

10. See notes 52-54, 60-62, 64 infra and accompanying text.

11. E.g., Jacuzzi v. Jacuzzi Bros., 32 Cal. Rptr. 188, 191 (1963); United States v. Standard Oil Co., 136 F. Supp. 345, 355 (S.D.N.Y. 1955). Cf. 8 WIGMrore, EvIDENCE $\$$ 2290 (3d ed. 1940).

12. See Kaufman, The Former Government Attorney and the Canons of Professional Ethics, 70 HaRv. L. Rev. 657, 659-60 (1957) ; Kaplan at 921.

13. In re Maltby, 68 Ariz. 153, 202 P.2d 902 (1949).

14. A.B.A. Or. No. 50; and see A.B.A. Ops. Nos. 33, 49, 72, 103.

15. Cf. Note, 64 YALE L.J. 917, 919 (1955), and cases cited therein.

The prevailing notion, however, is that a challenging ex-client must bear the burden of showing that confidences which he gave to another member of a lawyer's former firm were in fact passed on to that lawyer during his tenure with his old firm. Laskey Bros., Inc. v. Warner Bros. Pictures, Inc., 130 F. Supp. 514 (S.D.N.Y.), aff'd, 224 F.2d 824 (2d Cir. 1955) ; Gaver v. Early, 58 Cal. App. 725, 209 P. 390 (1922). But see Seaward v. Tasker, 143 N.Y. Supp. 257 (Sup. Ct.), appeal to the Fourth Dep't. transferred, 166 App. 
possibility that oral communication might serve to pass on the vital information, even the grant of civil discovery of firm files would be of limited utility to an aggrieved client trying to prove actual breach of confidence. Thus, the hard and fast rule is said to serve a prophylactic function by denying to law firms the ability ever to become involved in situations where confidences might be put to improper use.

The recent case of $W . E$. Bassett Co. v. H. C. Cook Co. ${ }^{16}$ gives judicial sanction to the disqualification rule as applied to the law firm. In that case, an attorney who had represented the Bassett Company for many years joined a new firm in 1958. This firm had represented the Cook Company from 1950 to 1953 on matters involved in a controversy between Cook and Bassett, ${ }^{17}$ although after 1953 the firm had ceased all representation of Cook. When the attorney joined his new firm, he retained the Bassett account, but stipulated that he was to receive no assistance from the other partners of the firm on the continuing Bassett-Cook dispute, ${ }^{18}$ that he alone was to receive the fees from the Bassett account, and that his proportion of the law firm's profits would not be reduced because of the Bassett fees which he was to receive. In addition, the Cook Company was notified of this arrangement before the attorney actually joined the firm, and the firm returned to Cook all of its files from the 1950-53 representation. Cook did not then object to the arrangement.

Despite the fact that the controversy had been in litigation in the federal courts since 1957, the trial judge was only informed of the new firm's prior association with Cook in 1961, when a formal complaint was lodged by Cook alleging that there was a conflict of interest, which disqualified the firm from representing Bassett. ${ }^{19}$ In an opinion of apparent sweeping generality, Judge Anderson ruled that irrespective of the good faith of the arrangement entered into by the attorney, neither he nor any other member of the firm could represent Bassett. The court regarded the fact that some members of the firm had been privy to Cook's confidences during $1950-53$ as a sufficient ground for disqualification in and of itself. ${ }^{20}$ Even Cook's apparent acquiescence in the Div. 903, 151 N.Y. Supp. 1144 (1913), rev'd on other grounds, 171 App. Div. 964, 156 N.Y. Supp. 243 (1915); and see Kaplan at 926.

16. 201 F. Supp. 821 (D. Conn.), aff'd per ctriam, 302 F.2d 268 (2d Cir. 1962).

17. Actually, the newly joined firm was successor to the one which had represented the Cook Co. during 1950-53. The partner who had represented Cook Co. at that time, however, was still active in the firm. Id. at 822 .

18. The attorney did make use of an associate of the firm, however, who argued a motion in court and appeared at a number of depositions and hearings in connection with the case. Brief for Appellee (2d Cir.), p. 4. The associate came with the firm after 1953. Brief for Appellant (2d Cir.), Appendix, p. 48a.

19. The Court first discovered the arrangement after the Bassett attorney moved under Rule 34 for discovery of files which had been prepared between 1950 and 1953 by his firm. $201 \mathrm{~F}$. Supp. at 821-22.

20. ... Attorney Dunham is the present partner of Mr. Cunningham, and Attorney Dunham's disqualification, ipso facto, disqualifies Attorney Cunningham and the other partners. ...

When Mr. Cunningham became a partner in Cooper, Dunham; Dearborn and Henninger, he and his partners took particular pains to segregate Bassett v. 
arrangement when it was first instituted was held insufficient to estop it from complaining of the conflict of interest, because, said Judge Anderson, "the court has a duty ... to see that the integrity and good name of the bar and the administration of the law are upheld."21 Judge Anderson found that the attorney for Bassett had conducted the case "at arm's length" from his new partners, and that there had been "no consultation or discussion with them concerning the case." $22 \mathrm{He}$ acknowledged further that the attorney "made every effont to comply with Canons 6 and 37 as ... [he] honestly interpreted them." 23 Nonetheless, the attorney was disqualified, solely because of the rule that every member of a law firm is disqualified from a representation when any one member of that firm is similarly disqualified on conflict of interest grounds. ${ }^{24}$

Judge Anderson's opinion seemingly left no room for any precautionary procedures which might have saved the abstention arrangement. Of particular interest was his failure to discuss the bona fides of the consent obtained by the Bassett attorney as a waiver device. It would appear from the opinion that there was nothing the firm could have done-even by having secured formal, written consent from Cook-to permit the incoming attorney to continue representing Bassett. Yet, if "express consent of all concerned given after a full disclosure of the facts" is obtained, Canon 6 apparently permits representations by individual attorneys which would otherwise be unethical on conflict of interest grounds ; Canon 37 seems to do likewise if "knowledge and consent" is present on the part of the ex-client. Judge Anderson's discussion of the factors which were dispositive for him in the case clearly indicated that - whatever the rule where individual attorneys were concerned-the mere presence of an intrafirm conflict always mandated disqualification irrespective of the form of consent given. By so delimiting the potential effect of waiver, Judge Anderson gave support to those interpretations of the Canons which speak of lawyers' "fiduciary" obligations to clients and ex-clients-obligations which clients may

Cook, et al. as Mr. Cunningham's personal case, unrelated to the partnership either by way of access to information, discussion or participation in proceeds; and it appears that they conscientiously sought to carry out this arm's length arrangement. They also made a full and fair disclosure to the $\mathrm{H}$. C. Cook Company. What they did not or could not change, however, were the two really significant facts which are determinative of this question: first, that $\mathrm{Mr}$. Cunningham and Mr. Dunham became partners; second, that Mr. Dunham had represented the defendant the $\mathrm{H}$. C. Cook Company and advised it concerning some of the most important issues in this case. These facts require Mr. Cunningham's disqualification in the present action.

$201 \mathrm{~F}$. Supp. at 824-25 [Emphasis added at second point].

21. Id. at 825 [Emphasis added].

22. Except, of course, when the initial arrangements were made to segregate the case. Id. at 822 .

23. Id. at 825 .

24. See note 20 supra. 
not permit their attorneys to waive except in the most innocuous of circumstances. ${ }^{26}$

The Second Circuit affirmed the holding in Bassett, but its brief per curiam opinion dealt with Judge Anderson's broad opinion in cryptic fashion, merely quoting with approval that part of the trial court opinion which stated:

Circumstances have now [been] created which, with the Bassett attorney remaining in the case, will inevitably lead to suspicion and distrust in the minds of the defendants and the opportunity for misunderstanding on the part of the public which will lead to a lack of confidence in the bar. ${ }^{26}$ The court did not, however, specify precisely what circumstances "now" disqualified Bassett's attorney. Perhaps the court had in mind the acrimony and duration of the dispute between Bassett and Cook, ${ }^{27}$ the fact that the trial judge did not learn of the special arrangements which had been made until relatively late in the litigation, ${ }^{28}$ the possibility that the Bassett attorney might have had to cross-examine one of his present partners, ${ }^{29}$ the fact that the attorney had attempted to hold the firm at arms-length from himself via a private representation, ${ }^{30}$ or the fact that formal written consent had not been

25. [T]here are extremely few situations in which a client will be permitted to cunsent to a violation of an attorney's fiduciary obligations. The exception of the Canon will permit such relatively innocuous representation of adverse interests as the preparation of a contract between two clients. As a general rule, however, the attorney's violation of the rules ... cannot be waived, since it is not within the client's power to waive. It must be remembered that an attorney is a servant of the state - an officer of the court - as well as a representative of his client. The client cannot waive the rights of the state.

Kaplan at 925. And see In re Boone, 83 Fed. 944, 957 (N.D. Cal. 1897); In re Themelis, 117 Vt. 19, 83 A.2d 507 (1951). Cf. Drinker at 89-96. But see Michel v. McKenna, 199 Wis. 608, 227 N.W. 396 (1929) ; Harvey v. Harvey, 202 Wis. 553, 231 N.W. 580 (1930); Guttwals v. Rencher, 60 Nev. 35, 98 P.2d 481 (1940).

26. 302 F.2d $26 S$ (2d Cir. 1962).

27. Interviews with participants and observers of the litigation uniformly described it as acrimonious. As to duration, see $201 \mathrm{~F}$. Supp. at 822.

28. See note 19 supra.

29. 201 F. Supp. at 825 ; and see A.B.A. Or. No. 220. A letter from a partner of one of the larger New York City law firms, sent in response to a confidential questionnaire sent by the Yale Law Journal to various law firms around the country, see note 59 infra, offered the following interpretation of the Bassett decision:

I think the Bassett case stands for the proposition that if an attorney is disqualified because of prior representation of another client from representing a new client, none of his partners can represent the new client in a contested litigation where his previous representation is an isstle.

Letter to the Yale Law Journal, July 13, 1962, on file in Yale Law Library [Emphasis added].

30. Such practice is distinguished from the "prototype" violation of the orthodox firm disqualification rule - where the individual attorney in possession of forbidden confidences abstains from participation in a firm matter. Firms generally permit their attorneys to represent clients "through the firm" only, and not "on their own." This may be presumed to be particularly true when the private representation is in conflict with a firm matter. Thus, no operative pressures exist on the courts to validate arrangements such as the one utilized in Bassett. 
secured from Cook when it had been notified of the arrangement regarding the Bassett attorney. ${ }^{31}$ Whatever the operative facts may have been for the Second Circuit, the per curiam opinion remains on its face inscrutable. ${ }^{32}$ Although the Second Circuit's affirmance in Bassett might be read as restricted to the narrow facts of the case, ${ }^{33}$ the court did not indicate disagreement with the broad generalization of Judge Anderson's opinion-that any individual disqualification within a firm always disqualifies the entire firm.

The impact of this broad disqualification rule has been heightened by recent enactment of the new Federal Conflict of Interest Act. ${ }^{34}$ That statute has reworked the rules governing the extent to which an individual, after leaving government service, is disqualified from representing interests adverse to the government. $^{35}$ Two categories of disqualification are specified. The individ-

31. The name partner of a New York City law firm of 16 attorneys wrote:

I wonder if the Bassett decision should not be limited to the holding that mere disclosure is not a stbstitute for the obtaining of specific approval to continue to participate, and absent specific approval, a firm may not represent either party to a matter where there is a possible conflict.

Letter to the Yale Law Journal, August 13, 1962, on file in Yale Law Library.

32. A partner of a small New York City firm wrote:

I think it is unfortunate that the Court of Appeals did not give the bar the benefit of its wisdom by enlarging upon its per curiam affirmance of the court below. In this day of specialization and movement of attorneys between firms as well as in and out of government, I feel that more definitive guidance would have been helpful.

Letter to the Yale Law Journal, August 14, 1962, on file in Yale Law Library.

33. Cf. Reply Brief for Appellant, p. 3, Bassett v. Cook, supra note 16, pointing out that an arrangement entered into by an ex-Attorney General of the United States would have been unethical under the terms of the district court opinion. The wide implications raised by the orthodox rule appeared not to have been raised by Bassett Co. until argument was made at the circuit court level.

34. 76 Stat. 1119 (1962), 18 U.S.C. \$\$ 201-18 (Supp. IV, 1963).

35. Before enactment of the new Act, two statutes had been in effect to deal with individual post-employment disqualification on conflict of interest grounds. The first, the former $\$ 99$ of title 5 , made it unlawful to prosecute a claim which had been pending during the employment tenure in a federal department of the ex-government official, against any department of the federal government for a period of two years. The statute provided no penalty for violation of its terms, however, and a subsequent Attorney General's interpretation limited the meaning of "department" to Cabinet offices only. See Assoctation of the Bar of the City of New York, Conflict of Interest and Federal Service 44-49 (1960) [hereinafter cited as Bar Ass'n Report]. The second statute, the former $\$ 284$ of title 18 , made it a criminal offense to prosecute a money or property claim against the United States within two years of federal employment if the claim was one the employee had been "directly connected" with while in the federal service. BAR Ass'N REPORT at 49-52. The acts were generally felt to overshoot their marks by barring the prosecution of claims on matters with which the ex-government employee had no personal connection. They were also felt to undershoot their marks by: (a) limiting all bans to two years only, (b) limiting proscribed activity to the prosecution of "claims," see United States v. Bergson, 119 F. Supp. 459 (D.D.C. 1954), (c) in the case of the former $\$ 99$ of title 5 , providing for no criminal penalty and restricting coverage to exCabinet employees only. See Perkins, The New Federal Conflict-of-Interest Law, 76 HaRv. I. Rev. 1113, 1153-54 (1963). 
ual is disqualified for his lifetime from representing any interests adverse to the government on matters in which he has been "personally and substantially" involved while in government service. ${ }^{36}$ Regarding matters which were merely "under his official responsibility" as a government official, the individual is barred for one year from "personally" appearing before any court, or governmental department or agency. ${ }^{37}$

The language of the statute neither accepts nor rejects application of the law firm disqualification rule. It is unclear from the statutory history whether application of the rule is to be implied. As passed by the House, the statute contained a clause that wherever the individual would be barred for his entire life, the individual's firm would be barred from representing those interests for two years. ${ }^{38}$ This provision was removed from the bill by the Senate at the insistence of the Justice Department. In the hearings before the Senate Judiciary Committee, the major witnesses heard on the issue of the House twoyear ban of firms were then Assistant Attorney General Katzenbach and Representative Lindsay, House sponsor of the bill. Assistant Attorney General Katzenbach argued that the provision should be eliminated from the bill in order to facilitate the recruitment of lawyers for government service by increasing their mobility upon leaving it. ${ }^{39}$ Representative Lindsay, while agreeing that mobility of government lawyers should be encouraged, felt that elimination of the statutory provision would leave the orthodox law firm disqualification rule in effect and thus might result in the disqualification of law firms for the life-time of the ex-government employee. ${ }^{40}$ The Senate Committee report adopted the Katzenbach suggestion and dropped the provision, but did not clearly state its reason for doing so. ${ }^{41}$ Thus, it is not clear whether the committee felt that the orthodox rule should be applied to firms hiring former government attorneys, ${ }^{42}$ or whether the committee merely meant to leave the question of firm disqualification to other institutions-to the courts and ethics committees in the case of the legal profession. In light of the substantial agreement by the witnesses in favor of a policy fostering the mobility of ex-government attorneys, it would seem that had the Senate meant to

36. 76 Stat. 1123, 1127-23 (1962), 18 U.S.C. $\$ 207$ (a) (Supp. IV, 1963).

37. 76 Stat. 1123, 1128 (1962), 18 U.S.C. \& 207 (b) (Supp. IV, 1963).

38. The provision was $\$ 207$ (c) of H.R. 8140 , enacted by the House in August, 1961. See Hearings on H.R. 8140 Before the Senate Judiciary Comnittee, 87th Cong., 2 d Sess. 5 (1961).

39. Id. at 21. The Assistant Attorney General's statement was a model in ambiguity, however, explicable only in terms of his feeling that the orthodox law firm disqualification rule was either never enforced or was soon to be modified by the courts and ethics committees.

40. See Hearings on H.R. 8140, supra note 38 , at 36-37.

41. See S. REp. No. 2213, 87th Cong., 2d Sess. 13 (1962).

42. Support for that view is to be found in: (a) the failure of the Senate Committee to affirmatively endorse the Katzenbach-Lindsay dominant notion - that the firm disqualification rule should be liberalized to attract able lawyers into Government service, and (b) the suggestion in the report that it was inappropriate to deal with the law firm disqualification provision in a criminal statute. 
adopt the harsh disqualification rule it would have done so explicitly. Moreover, the fact that the witnesses before the Committee were in sharp disagreement on the means of effectuating the policy of encouragement of mobility and the fact that the major concern of Congress was focused on other aspects of the legislation, suggest that the Committee meant to abstain from dealing with an issue which it knew to be complex and thought to be of relatively low priority. ${ }^{43}$ This conclusion is also supported by the testimony which advised the committee to leave the problem of law firm disqualification to the Canons of Ethics, which were thought to provide adequate supervision and protection in situations involving those in the firms of ex-government attorneys.

The consideration of mobility may itself be a sufficient reason not to apply the inflexible rule to the firms of former government attorneys. By cutting down on attorney mobility, the broad disqualification rule may entail a correlative loss of certain values generally thought desirable by the legal profession and the institutions it serves. For example, unless government service could be followed by a reasonable possibility of private practice, many lawyers would refuse to work for the government. ${ }^{44}$ The government may be more concerned with attracting legal talent by insuring mobility after government service than with protecting its confidential relationship with its lawyers. ${ }^{45}$ Moreover, while the government is interested in attracting lawyers for permanent service, there may be considerable social value in encouraging an influx of lawyers into government service for temporary employment. ${ }^{46}$ Finally, legitimate government concern with excessive staff turnover can be accommodated by insistence on long-term employment commitments. ${ }^{4 \mathrm{aa}} \mathrm{A}$ flow of information between the government and the outside, generated by attorney mobility, is of great value both to the government and to the private interests represented by attorneys, as well as to attorneys themselves. ${ }^{47}$

43. See S. REP. No. 2213, supra note 41 , at 13 . The Senate Committee indicated that the use of confidences by the associates of ex-Government attorneys was not as serious a matter as the other problems dealt with by $\S 207$.

44. See BAR Ass'r Report at 224:

[N]o man will accept government appointment - especially temporary government appointment - if he must abandon the use of his professional skills for several years after leaving government service.

And see Kaufman, supra note 32, at 668. Cf. a letter from a Washington, D.C. law firm. We would not hire any attorney from Government service who had had any contact with matters on which the firm was engaged or might likely be engaged in the future. Attorneys leaving the firm have sometimes left for Government service, often in a non-legal capacity, and returned where no conflict questions were present. The Canons have on accasion prevented us from associating with this firm a lawyer of distinction who would otherwise have joined us.

Letter to the Yale Law Jonrnal, July 11, 1962, on file in Yale Law Library.

45. See note 39 supra and accompanying text.

46. See Rostow, The Lazeyer and His Client, 48 A.B.A.J. 25, 147 (1962).

46a. The Treasury Department requires a minimum promise of four years' service for all attorneys it now hires. Wall Street Journal, May 13, 1964, p. 1, col. 7 (Eastern ed.).

47. [S]omething must be said of the effect of post-employment restraints on the government itself. It is not sufficiently recognized that post-employment restrictions 
There are also unfortunate effects of the rule as applied to purely private practice. Law firm disqualification may reduce the mobility of lawyers in private practice insofar as a firm weighs the possibility that the hiring of a new attorney might disqualify the firm from representing present or future clients. ${ }^{48}$ Indeed, many firms take on more young associates than can possibly be integrated within the firm. ${ }^{49}$ To the extent that the conflicts of interests rules tend to diminish severely the mobility of associates not invited to partnership, the rules would appear to create substantial hardship. ${ }^{50}$

Of equally critical significance is the general characteristic of conflicts of interests problems, that the most severe detriment resulting from a disqualification is often imposed on the client forced to give up his attorney. ${ }^{51}$ Aside from the major inconvenience of forcing clients to make periodic shifts of counsel on varying matters, the strong possibility of unexpected conflicts developing among clients of a firm makes it possible that many clients will have to forego the aid of long standing counsel at the moment of most critical need.

Disqualifying conflicts of interest arise in a variety of situations of common occurrence in daily practice. Often two clients represented by the same firm develop antagonistic interests : the firm might be disqualified from represent-

can be overly stringent, hurting the government more than they help it. This is most easily seen in the deterrent effect of such regulation upon the government's recruitment of manpower; no man will accept government appointment - especially temporary government appointment - if he must abandon the use of his professional skills for several years after leaving government service. The adverse effect of such restrictions on the government's efficient use of skills and information is probably even greater. The knowledge of an experienced former official may be made to operate against the government, but it may also contribute to the ends of the government. . . . It is directly to the government's interest to have the skills of the tax specialist put to use in the solution of tax problems. When a former employee of the Urban Renewal Administration helps a city prepare an application to that agency, his experience is being used directly to further and speed up a program of the federal government. Federal government policies such as antitrust policy or pure food and drug protection are clearly advanced by the presence in the private segment of the economy of men steeped in government experience.

BAR Ass'N Refort at 224. See also, note 58, infra.

48. See Letter from a Cleveland firm,

The Bassett decision spotlights a problem of which we have been aware. It has affected the time of employing people in the past and will continue to do so....

We cannot say for certain how the Bassett case will affect our procedures in the absence of a specific problem. We will certainly be careful in considering the holding.

Letter to the Yale Law Journal, August 24, 1962, on file in Yale Law Library.

49. See Klaw, The Wall Street Lawyer, Fontune, February, 1958, p. 197.

50. See Harmar Drive-in Theatre v. Warner Bros. Pictures, Inc., 239 F.2d 555, 559-60 (2d Cir. 1956) (dissenting opinion); Note, 64 Y ALE L.J. 917, 928 (1955).

51. See Laskey Bros., Inc. v. Warner Bros. Pictures, Inc., 224 F.2d 824, 827 (2d Cir. 1955) ; In re Trimble's Estate, 392 Pa. 277, 140 A.2d 609, (1958); Note, supra note 50 , at 928 . 
ing either client in a substantial number of matters. ${ }^{52}$ Such unexpected conflicts, either between current clients or between a current and past client, are particularly to be expected in the smaller metropolitan centers, where a small number of law firms handle much of the area's substantial commercial practice. ${ }^{53}$ The problem frequently appears in the larger cities as well, however, where the firm represents a full roster of major commercial clients whose very size and range of operation make it inevitable that they come in conflict on a more or less regular basis. ${ }^{54}$ The incidence of sudden conflicts between current or past clients may also be aggravated by the growing specialization among some law firms. As a firm's business is conducted within increasingly narrow scope, the class of potential clients is usually reduced correspondingly. Another factor influencing the probability of creation of sudden conflicts is the relative growth in size of the law firm: $:^{55}$ as a firm takes on more clients the mathematical probability of an intra-firm conflict increases. Additionally, the larger law firms no longer can, and in many cases no longer wish to require exclusive and unbroken tenures of service as conditions of employment and partnership $;^{; 6}$ the potential for conflict is correspondingly increased. As

52. A New York City lawyer offered the example of the following situation, ". . . which unfortunately has occurred several times in our office."

Client A, represented by the firm, entered into business dealings with $B$ corporation. Subsequently, B corporation retained the firm to do its legal work, and dealt solely with another member of the firm who had no contact or involvement with Client A or any of his legal problems. After passage of a period of a year or so, Client A finds it necessary to bring action on the contract against B corporation, who at that time is also generally represented by the firm.

... Under these circumstances, the individuals who were representing Client $A$ had no connection with the $B$ corporation; and the individuals who were doing the work for the $B$ corporation were totally unaware of the problems pertaining to Client A. Nevertheless, because of the dangers inherent in a situation where the law firm represented both parties, it was necessary for the firm to take no representation whatsoever in the litigation between Client A and B corporation.

Letter to the Yale Law Journal, August 13, 1962, on file in Yale Law Library.

53. A law firm which has been able to recruit a number of excellent lawyers from around the country is generally regarded as the "best" firm in its county, one of the fastest growing in the United States. Until three years ago the county was largely rural and its established practitioners generally lack experience in complex commercial matters. Although a number of law firms from an outlying urban community have increasingly been servicing the county, and a few have in fact made plans to foster the opening of either "correspondent" or "branch" firms in the near future, the firm is faced with the daily call to mediate between developers, land owners and financing institutions.

Although in form not quite so stark, the same situation obtains in many medium sized communities able only to support a small number of firms capable of handling certain types of commercial matters. Interviews, President —— Bar Association, July, 1963; Dean, —_ (State) Law School, December, 1963.

54. This is particularly true when the firm represents a bank, a client whose business it is to involve itself in loan negotiations with as many commercial clients as possible.

55. Smigel, The Wall Street Lawyer 351 (1964).

56. Interviews, New York City lawyers. What is true of the larger New York City firms in this respect is a fortiori so for most other metropolitan law firms, given that, in 
these trends in the practice of law accelerate, the inflexible law firm disqualification rule-particularly if waivers by affected clients are not considered effective-is rendered increasingly impractical.

The rule is premised in the day when firms, when they existed, were very small-also a day when attorneys most frequently could think of their activities in terms of discrete "matters." Increasingly, neither condition obtains. In many large metropolitan law firms it is to be doubted whether a partner or associate shares the intimate daily contact with his business associates which is one basis for the inflexible law firm disqualification rule. ${ }^{57}$ There may be a "team" with whom he has such contacts, and files of his which others ought not to see; but to disqualify the entire firm because of his participation in some matter is to put great weight on a tenuous thread. Similarly, the premise of the rule that conflicts exist with respect to "matters" is substantially defeated by the ongoing nature of many attorney-client relationships. Where a lawyer engages in a continuing course of consultation with his client across a broad spectrum of legal issues, it becomes both difficult to identify the existence and dimensions of a "conflict of interest" and likely that, in perspective, neither lawyer nor client will be as much affected by the conflict as by the disruption a disqualification may bring about. Finally, clients, like their law firms, are often more sophisticated and legal matters are often more complex than the absolute rule suggests. ${ }^{58} \mathrm{~A}$ large corporate client is perfectly capable of assessing the balance between the value of continued service by its firm and the dangers which might arise when a conflict is presented. Its consent ought not only to be respected, but is also to be anticipated.

It cannot be expected that the changes in practice which have called the premises of the rule into question will be reversed, or that they can be reconciled with the rule's continued operation. The growing complexity of the law and the growing range of interests of the clients it serves render increasing firm size a necessity. So does the rapidly expanding need for expensive physical plant-libraries, computers, and the like-and staff. And, with increasing firm size and complexity, a rigid rule would find progressively in-

the past, New York City firms have been relatively insistent on tenures of service unbroken except during times of war and national emergency. Today, little value may be said to attach to such insularity. See note 47, supra; and cf. Klaw, supra note 49 at 141-42. A reluctance to permit leaves of absence for governmental and other related public service has been found by firms to diminish their ability to attract many of the most promising prospects. The reluctance to hire lawyers who have worked with other firms or for the government prior to any service with the hiring firm is also on the wane, here most probably hecause of increasing recruitment competition among the firms for the better lawyers.

57. See SMrgeL, op. cit. stpra note 55 at 224-26.

58. Sophistication breeds ability to deal self-sufficiently with conflicts problems, even hefore they arise. For example, government legal departments may, via their rule-making powers, set down pre-employment conditions of service - rules which suitably balance the recruitment and secrecy needs of the particular agency. See, e.g., the agency rules discussed in McElwain \& Vorenberg, The Federal Conflict of Interest Statutes, 65 HaRv. L. Kev. \$55, 972-74 (1952). Cf. A.B.A. Op. No. 306, modifying A.B.A. Or. No. 296. 
creasing application. The impact of continued enforcement of the rigid rule will, it would seem, blunt the law firm's growth by denying it the advantages of size and by forcing its clients repeatedly to lose the benefit of independent representation at moments of critical need.

It may not be surprising, in this context, that actual practices regarding conflicts of interest appear far from complying with the inflexible rule, regarding either government or private client conflicts. In the paradigm situation-representation of two parties currently opposed in litigation-violation of the Canons does not appear to be common: such circumstances tend to acrimony, are readily identified, and, it is generally agreed, present an imperative occasion for the rule. ${ }^{59}$ Where confidences of past clients are involved, or where negotiating or planning activity on behalf of concurrently opposed parties is involved, however, compliance is less common. A Yale Law Journal survey ${ }^{59 a}$ among numerous law firms in large metropolitan centers revealed a wide acceptance among firms of the practice of representing a client in these circumstances despite the presence in the firm of attorneys who would themselves be disqualified from the representation, ${ }^{60}$ particularly when consent had

59. See note 79 infra. But see the letter of a New York City firm:

We have, on occasion, asked new employees or even partners not to do any legal work for a client where a conflict with a regular client might exist. The capacity in which the participating attorney may act has no bearing on the decision, if there is such a conflict.

Letter to the Yale Law Journal, July 3, 1962, on file in Yale Law Library.

$59 \mathrm{a}$. In an attempt to gauge the impact of some of the problems raised by the Bassett decision, the Lawe Journal in the Spring of 1962 sent out a questionnaire to 175 law firms of varying sizes located in various metropolitan centers around the country. Of the 175 firms, 100 were located in New York City where a wider sampling of variously sized firms was obtained. Those queried outside of New York tended to be the larger commercial firms within their communities. Responses were received from 79 firms, a remarkable rate of return in light of the detailed nature of the questions. The questions were designed to bring out information regarding hiring policies of firms in light of conflict of interest problems, possible policies of individual abstention indulged by firms, and conflict discovery procedures utilized by the firms. Thanks are extended to those who were kind enough to respond.

60. A Chicago firm related the following experience:

The matter concerning which you have inquired is one which has not previously been a problem for this firm. We have, however, recently faced a similar issue in an anti-trust case in which counsel for the plaintiff severed his connection with the firm of which he had been a member at the time the suit was brought and proceeded to form a partnership with an attorney who had, prior to the moment of the formation of such partnership, been a partner in a two-man firm representing one of the co-defendants. When this matter was brought to the attention of the District Judge he indicated an unwillingness on the Court's own motion, to disqualify plaintiff's counsel. After reflection, defense counsel determined to make no formal motion.

Letter to the Yale Lare Journal, August 3, 1962, on file in Yale Law Library.

A Philadelphia firm wrote:

Our firm has had occasion to ask its members or associates to abstain from participating in matters in which the firm continues to participate ... where our 
been obtained. ${ }^{61}$ Where a firm represents concurrently conflicting interests, the practice is sometimes followed of "splitting up" the firm into separate teams of lawyers, each of which represents one of the antagonistic clients. ${ }^{62}$

relationship with a regular client makes it impossible for us to take on the representation of a client with an adverse interest.

Letter to the Yalc Law Jonrnal, July 11, 1962, on file in Yale Law Library.

Most openly, a New Orleans firm wrote:

We admitted a partner about two years ago who resigned a partnership in another firm to join us. Several pending litigated cases originating prior to his resignation from his prior firm involved both firms. Since joining us we have abstained from having this new partner participate in any way in the pending litigation. We do not deem it necessary under the Louisiana Canons of Ethics to withdraw from those cases regardless of the holding in Bassett.

Letter to the Yale Law Journal, July 13, 1962, on file in Yale Law Library.

But cf. the following responses of other New Orleans firms to the questionnaire:

I would like to state simply this, i.e., that we have always disqualified ourselves from handling any matter where there would be a past or present conflict as respects clients or as respects representations or interests of any of our partners or associates. Accordingly, we are in nowise affected by the decision which is discussed.

Letter to the Yale Laze Jottrnal, July 20, 1962, on file in Yale Law Library.

As a matter of policy and irrespective of what the law might be, our firm would not accept employment where intra-firm problems of prior representation are involved. Our firm has at all times declined employment where there is the least question of a conflict. Our firm does not permit any of its members to engage in private representations at arm's length from the rest of its members.

Letter to the Yale Lau Iournal, July 6, 1962, on file in Yale Law Library.

The Government can indulge in abstention procedures as well. A Baltimore firm reports:

We like to have our assaciates secure training for a year or two in the office of the Attorney General of Maryland or of the United States Attorney. At most times we have one or more associates on loan to these offices. We arrange with the Attorney General of Maryland or the United States Attorney that the associates will not be required to handle any matters in which this firm participates.

Letter to the Yale Lazo Journal, July 2, 1962, on file in Yale Law Library.

61. I have always understood that although seriously frowned upon, an attorney might represent both parties to a transaction if he has received the approval of both such parties. A written instrument to that effect is of course desirable to evidence such approval, but a determination by the Court of the fact that such approval was given should have been sufficient, it would seem, to avoid the result in the Bassett case.

Letter from a New York City firm to the Yale Laze Journal, August 13, 1962, on file in Yale Law Library.

62. A New York City lawyer whose firm has permitted the representation of concurrently adverse interests - albeit under circumstances of consent and in non-litigation situations - reports as follows:

The industriousness with which the job is pursued when two members of the firm represent adverse parties is greater than in any other circumstance $I$ have seen. Whether because competition between partners is generally keener or out of fear of the subsequent reaction should one of the men blunder, I don't know. It happens nonetheless.

Interview, Yale Law School, April, 1964. 
Furthermore, many firms interpret the disqualification rule as applying only to conflicts arising from matters handled by partners of the firm, and accept clients when a conflicting interest has been represented by an associate within the firm. This restriction of the rule to partners is also used to justify designating some attorneys within the firm as "of counsel," so that the firm may represent interests it otherwise clearly could not represent. Use of the "of counsel" status is particularly prevalent regarding attorneys who leave high positions in Government service to enter private firms. ${ }^{63}$ In addition, some firms formally reconstitute themselves into separate partnerships when new matters involving possible conflicts of interest are taken ;64 yet these "separate" partnerships continue to use the same facilities and remain generally in as intimate a professional contact as had obtained prior to the split.

The apparently inadequate practices for discovering conflicts of interest within firms give further indication of the way in which the orthodox firm disqualification rule is being ignored in practice. Many firms make less than a full effort to uncover potential conflicts. ${ }^{65}$ Even in those firms which do attempt to uncover them, the existence of conflicts often goes unnoticed and uncorrected until the handling of matters is well under way. New business is frequently discussed at weekly or bi-weekly partners' meetings, which often have substantially less than full attendance, and are often viewed essentially as social gatherings and as occasions for addresses by senior firm members; in such situations genuine interchange of information may be impossible. ${ }^{6 n}$

63. See BAR Ass'N Report at 228.

64. Id. at 228-29. And see letter from a Philadelphia firm.

In two or three instances where one of the partners was serving on a board, such as a school board or in the legislature, we have organized a separate partnership to handle certain matters. This has not been done for a number of years.

Letter to the Yale Law Journal, July 6, 1962, on file in Yale Law Library. See Bagdikian and Oberdorfer, Confict of Interest - Can Congress Crack Down on Its Ozen Mombers, Saturday Evening Post, Nov. 17, 1962, p. 27 for a discussion of the dual-firm arrangement empoyed by an incumbent congressman.

65. A major San Francisco firm, one of the largest in the city, reports as follows: The discovery of possible intrafirm problems of prior representation is handled, quite simply, by conversation between the partners.

Letter to the Yale Law Journal, August 16, 1962, on file in Yale Law Library.

A New York firm with 22 lawyers, two-thirds of whom have served with other firms at one point in their careers reports that "informal conversation" is employed to discover conflicts. "Casual conversation" is the discovery system of a New York City law firm of 21 lawyers, only ten percent of whom have served their legal careers exclusively with the firm.

66. A rare exception to the rule is a Philadelphia firm, which reports:

This Firm continues an unusual policy, which it has followed from its inception, i.e. all partners meet together at 9:15 every morning of the week except Thursday. At these meetings, one of the most important pieces of business discussed is the matter of legal representations that have been offered to us and the question as to whether this representation would in any way create a conflict with the representation of any existing client. Frequently, where we have been asked by an existing client to represent it in a matter which would put us in conflict with 
Even where the meetings are regarded as more business-oriented, possible conflicts problems usually are an incidental part of the agenda. In many instances, the only information given is a bare recitation of the new retainers with no description of the nature of the business undertaken. ${ }^{67} \mathrm{New}$ problems of current clients often go unannounced, or the information given may be too incomplete or cryptic to permit easy identification of potential conflicts problems. Furthermore, associates, particularly in the larger firms, often do not participate in these meetings at all, and are given no opportunity to identify potential conflicts of interest. While some firms also circulate inter-office memoranda regarding new business, they usually go only to partners, and their description of new business is often inadequate. ${ }^{68}$ And there are some firms in which the check of firm files constitutes the sole means of conflicts discovery ${ }^{60}$

The sufficiency of all of these practices appears suspect in light of the policies expressed by the orthodox disqualification rule. The "of counsel"

the interests of another existing client, we have noted this fact to both clients and suggested that each seek other counsel in the matter.

Letter to the Yalc Law Journal, August 17, 1962, on file in Yale Law Library.

67. We have no definite procedure for discovery of conflicts and depend on weekly luncheon meetings at which a list of new cases is read to the assembled partners, reports one of the larger Baltimore firms. Letter to the Yale Law Journal, August 1, 1962 , on file in Yale Law Library.

68. With infrequent exception, all of the firms who utilized a memorandum system submitted the memoranda to partners only. A large New York City law firm was an exception:

We circulate a notice of each new item of prospective legal business as soon as it is first initiated. This goes to all partners and all associates. This is very effective in preventing us from representing two sides in a controversy or from otherwise getting into a position adverse to another client.

Letter to the Yale Law Journal, August 3, 1962, on file in Yale Law Library.

An Atlanta firm follows a similar procedure:

We have no set procedure for finding out whether there is any conflict of interest, but of course we do check in all matters to be certain that there is no conflict. A description of each new matter and the parties involved goes to each partner and Associate at the inception - as well as to our Administrative Committee.

Letter to the Yale Law Journal, August 2, 1962, on file in Yale Law Library.

69. See letter of a Portland, Oregon firm:

Our file clerk has a cross-index client file and if there is any question about conflicts in representation the cross-index file is first consulted and then a conference will follow between the partner to whom the new business is referred and the partner who has represented another client with a possible adverse interest.

Letter to the Yale Law Journal, July 10, 1962, on file in Yale Law Library. Compare the letter of a Baltimore firm:

This firm maintains a card index which contains alphabetically a list of all matters which have been handled over a number of years. This has not proven satisfactory because of the frailty of human nature in properly indexing all matters. We, therefore, have adopted the practice of giving all partners a list of all subject matters which have been placed on our books during the preceding week.

Letter to the Yale Law Journal, July 2, 1962, on file in Yale Law Library. 
label, or status as an associate rather than a partner, in and of itself hardly stands in the way of free exchange of confidences. Reconstitution of the firm into separate partnerships for conflict of interest purposes, or splitting a firm in order to represent concurrently conflicting interests, or abstention from a particular matter by one member of the firm is no less offensive to the policy of the disqualification rule insofar as contact among these separated lawyers continues and could lead to a sharing or appearance of sharing the forbidden confidences. Even the common practice of securing permission from affected clients as a way of validating these procedures is placed in some doubt by Judge Anderson's opinion in Bassett v. Cook.

Yet the practices persist. If representation of a client by a firm in which one member is disqualified from the representation creates an "appearance of evil," then the appearance of evil-as well as the potential for actual disclosure of forbidden confidences-is rife. According to doctrine, if this evil is to be avoided, law firms must discontinue these practices and adhere to the letter and spirit of the firm disqualification rule. It is submitted, however, that the present practices among law firms reflect legitimate interests made emphatic by the changed nature of legal practice. The social values of mobility from government service into private practice and of mobility among private firms, the harsh effects of depriving clients of counsel, and the impracticability of the current firm disqualification rule as evidenced by its wide disregard, argue for modification of the orthodox rule. Although a strong countervailing policy - that clients' confidences should not be used against them by their attorneys -must also be accommodated, the problem is one of balance between this interest and those which oppose the orthodox rule. The striking of such a balance necessarily involves a departure from the present, inflexible rule.

One possible resolution is to retain the rule, but to construe narrowly the occasions for disqualifying the individual attorney because of his past representation of arguably antagonistic interests. For example, the leading opinion on disqualification of ex-government attorneys appears to use this device to avoid, at least partially, the draconian effect of the firm disqualification rule. ${ }^{\text {n }}$

70. United States v. Standard Oil Co. (N.J.), 136 F. Supp. 345 (S.D.N.Y. 1955). The Government sought to disqualify an attorney who had headed the Paris office of the European Cooperation Administration in a suit brought against Standard Oil by the E.C.A. for alleged overcharges to the Government. The action was brought less than six months after the challenged attorney had resigned his E.C.A. position. In an elaborate opinion, Judge Kaufman found no substantial relationship between the attorney's former position and the issues in the case and therefore permitted the attorney to continute in the suit. Because of Judge Kaufman's support of the orthodox firm disqualification rule, $136 \mathrm{~F}$. Supp. at 360 , it is reasonable to assume that, in light of his sympathy for the difficulties of government recruitment of attorneys and the value of a cross-fertilization between attorneys in the private and public sectors, see Kaufman, stpra note 12, at 668 , he was less harsh in ordering the disqualification than he would otherwise have been had the ex-E.C.A. lawyer been permitted to abstain from the case. Query whether a greater "appearance of evil" was not fostered by allowing an attorney to defend a client in a multimillion dollar suit only a short while after he had resigned as chief counsel of 
This approach is unsatisfactory however. In essence, it seeks to sustain the premises of the rule by lessening the range of its applicability. Yet, as to the individual attorney, narrow construction creates the "appearance of evil" in its most dramatic form. A disturbing picture is presented to the public at large whenever an individual attorney is found in a position of active involvement in a suit against a government agency he has worked with or when he operates against other former clients - even if, on the basis of a close analysis, his past participation is viewed as something less than "personal and substantial." Also, for the law firm, disqualification may be imposed under the inflexible rule in a range of circumstances which, however narrow, are not justified by the particular need to protect confidences or appearances in that case. If the assumptions about the nature of law practice which underlie the law firm disqualification rule are made difficult by modern conditions of legal practice, they would seem no more valid if the individual disqualification which triggers its occurrence is narrowly rather than broadly applied.

The alternative to narrowed construction of individual disqualification accompanied by application of a strict rule of law firm disqualification is a rule which would qualify representation by a law firm in some circumstances in which one of its members would be disqualified. Such a rule would necessarily be oriented to judicial discretion: the judge must be convinced that, under the circumstances, the law firm has acted intelligently and with awareness to contain disqualifying confidences in a sector of the firm withheld from the case at bar. ${ }^{71}$

A necessary precondition to the adoption of such a modification would seem to be more efficient procedures for discovering and dealing with conflicts of interest than exist within many firms. For example, memoranda might be circulated to all lawyers within the firm, describing the new business in reasonable detail. In addition, the checking of firm files and the direct questioning of those members of the firm likely to have conflicts problems could be undertaken. Within larger firms in particular, formal designation of a committee with primary responsibility to effectuate the necessary procedures is desirable. ${ }^{72}$ True, it must be recognized that discovery of impending or even actual conflicts among present or past clients is not an easy task. Continuing representation of large national corporations does not readily permit the delineation of a firm's work into those discrete "matters" so necessary for an effective conflicts discovery process. Moreover, security problems may well exist; if a client is contemplating a merger, a stock split, or any other plan

an important branch of the suing agency than would have been the case had he been disqualified and his firm permitted to continue representing its long standing client in the matter. See also, In re Advisory Opinion of Ky. State Bar Ass'n, 361 S.W.2d 111 (1962).

71. On the return of discretion to the trial judge, rather than the maintenance of an inflexible rule, cf. Thomas v. Cassidy, 249 F.2d 91, 92 (4th Cir. 1957) ; In re Spicer, 126 F.2d 288, 289 (6th Cir. 1942).

72. Such an arrangement appears to be a more general practice in the Washington, D.C. area than in most other communities. 
of sensitive nature, leakage might well jeopardize the transaction. ${ }^{73}$ Such problems pose limitations on the extent to which circularization of memoranda can be expected to accomplish discovery of all conflicts. Given inherent restrictions on the efficacy of the discovery process, ${ }^{74}$ including realistic time and energy limitations, a finding that a firm has exercised its best effort to effect conflicts discovery should caution against automatic disqualification even of a firm whose discovery of a real conflict came well after a representation had begun.

Once a conflict has been discovered, the firm could, of course, decline the conflicting business. But the judge should be prepared to accept alternatives devised by the firm, if they safeguard the interests of antagonistic clients. A necessary act which the firm would perform in this regard would be the immediate notification of all parties, both of the existence of a conflict and of the steps by which the firm proposes to continue with the representation. Then, if the parties consent to the firm's proposal, the representation should be allowed to continue except in the most unusual circumstances. This result would be in line with the language of the Canons, which permits the representation of adverse interests by an individual attorney when consent has been given; it would not be a major change to honor consent to firm representation even if that consent excluded a particular attorney as disqualified. Indeed, the case for allowing consent to representation by a law firm is the stronger one, given the greater ease with which a law firm, as opposed to an individual, can divide its loyalties.

The exceptional circumstances, in which consent could not operate to validate representation, seem to fall almost entirely in the area of litigation. Thus, should the representation ever reach litigation, notification to the court of the arrangements made would be necessary, and, private agreement by the parties notwithstanding, the court could still exercise its power to reject or modify such arrangements. Bassett itself suggests one such factor. When the possibility exists that an attorney may be called upon to cross-examine another

73. Cf. the report of a Philadelphia firm:

There have been situations ... . in which one lawyer will be acting for a client which competes with a client represented by another lawyer in the office. Although there is no conflicting interest, we do try to keep confidential the affairs of each client so that neither will be put at any competitive disadvantage.

Letter to the Yale Law Journal, July 11, 1962, on file in Yale Law Library.

74. A Wilmington, Delaware firm whose discovery procedures are as elaborate as can reasonably be expected indicates certain inevitable limitations in any such system.

Each new matter undertaken by the firm is reported upon a weekly list which is sent to each lawyer in the firm. These lists are immediately reviewed by each lawyer and collectively reviewed by a committee of partners at least every two weeks. This does not ensure avoidance of conflicts because the lawyer who has knowledge of the facts on which a conflict is based may not have the opportunity to see the lists or express his views promptly.

Letter to the Yale Law Journal, July 6, 1962, on file in Yale Law Library. 
attorney within his firm, the representation ought not to be permitted ${ }^{75}$ such cross examination would place both lawyers in positions sufficiently ambiguous as to cast reasonable doubt on their ability to fulfill their respective roles as examiner and witness. Clearly also, if a concurrent conflict within a firm approached the litigation stage, at least one of the representations would have to cease. $^{76}$

If one of the parties to the conflict-for example, the past client of a lawyer now with the firm of its antagonist-refused to acquiesce in the arrangement after notification, a court or ethics committee, following inquiry into the proposed method for handling the conflict, might still decide that the representation could properly continue. The primary issue involved in the determination of questions of firm disqualification should be the extent to which the firm can realistically be expected to insulate disqualified attorneys from all participation in the matter in question. Relevant to this issue would be firm size and organization-How likely are the disqualified attorneys to come into close and repeated association with attorneys participating in the case? If law firms show active concern for conflicts problems, especially by formalizing treatment of conflicts of interest within the firm, then a court might rely on the existence of a strong sense of ethical conduct within the firm - evidenced by discovery, notification and insulation procedures - to reasonably deduce that in these circumstances past or current clients need not fear abuse of confidence. ${ }^{77}$

75. See note 29, supra. Cf. the response of a Cincinnati firm:

The Bassett case seems to us to present a highly questionable method of legal practice inasmuch as [the Bassett attorney] was asking for production of his own firm's papers. In a similar situation I doubt if many firms would undertake such a representation - or permit a partner to undertake such a representation. Certainly I don't think our firm would consider it.

Letter to the Yale Law Journal, July 12, 1962, on file in Yale Law Library.

76. A large New York law firm follows that very rule.

On occasion, we have after full disclosure to and consent from all parties acted as advisers to different parties whose interests were not the same. This is not done by us in the case of an adversary proceeding such as litigation. While I am not an expert in the field of the Bassett decision, it would seem perfectly clear to me that where one member of a firm was disqualified by prior representation from representing a party in litigation, the entire firm would be disqualified on general principles of partnership and agency law.

Letter to the Yale Lave Journal, July 5, 1962, on file in Yale Law Library.

77. There must be a point at which some element of trust must enter into the enactment of rules of legal ethics. Professor Seavey, the author of a brief in one of the leading disqualification cases, makes the apt point that:

The aphorism that Caesar's wife must be above suspicion is based upon a distrust of her virtue.

Petition for Rehearing, p. 2, Harmar Drive-In Theatres v. Warner Bros. Pictures, Inc., 241 F.2d 937 (2d Cir. 1956). With opportunities for abuse of trust as rife as they are for the practicing attorney, it must be questioned whether rules based on a distrust of attorneys can really generate compliance. 
Perhaps the major problem involved in any modification of the orthodox law firm disqualification rule is to be found in the general attitude of the Canons and the spirit of those that interpret them. Once described by Chief Justice Stone as "generalizations . . . for the most part ... . designed for an earlier era,"78 the unreality of the Canons is well indicated by their statement that partnership as opposed to individual practice "is not to be condemned." The law firm has become the organic institution for the practice of private law; ${ }^{80}$ such half-hearted approbation of firm practice demonstrates how far the Canons stand from contemporary norms of conduct for legal practice. There are firms today with over a hundred attorneys; inter-city law practices already exist; and national law firms may not be far in the future. ${ }^{81}$ It is fair to assume that such developments threaten the lawyer's cherished self-image as an independent practitioner. That assumption, however, serves as the best reason why the Canons ought to face such problems articulately and directly, rather than to allow a wistful feeling for older days to prevail. Ignoring the implications of modern legal practice, via maintenance of out-dated Canons, has led to the circumvention of the rules and the creation of legal fictions. If a process of law is to superintend the development of the legal profession, its rules must come closer to reality than do the Canons. ${ }^{82}$ Courts

78. Stone, The Public Infuence of the Bar, 48 Harv. L. Rev. 1, 10 (1934). A letter from one of the nation's most distinguished practitioners, a Washington, $D$. C. lawyer puts it in the following manner:

A clarification is badly needed because the applicable Canons undoubtedly developed in the context of smaller firms when our society was less complex and the interchange between Government and private representation was less frequent and lines of demarcation clearer.

Letter to the Yale Law Jonrnal, July 11, 1962, on file in Yale Law Library.

79. American Bar Association, Canons of Professional Ethics No. 33. Cf. Willson v. Willson, 5 N.J. 791 (Sup. Ct. 1820).

80. See Freund, The Legal Profession, 92 DaEdalus 689 (1963). See generally, Blaustein \& Porter, The American Lawyer (1954). Cf. Caritn, Lawyers on Their OwN (1963).

81. Cf. Bar. Ass'N RePort at 229; Perkins, The New Federal Confict-of-Interest Law, supra note 35 at 1162 .

82. Further, Judge Kaufman has described the approach of the Canons as follows: Professional canons of ethics are not designed for the Holmes' "bad man" who wants to know just how many corners he can cut without running into trouble with the law. They are drawn rather for the "good man," or ethical man, as buoys to assist him in charting his professional career.

Kaufman, supra note 12 at 657 . The problem with such an approach lies in the fact that the Canons possess the "bite" of sanctional law, see Note, 57 CoLunrara L. Rev. 994 (1957), and as such cannot take on the exclusive form of homilies for the pious lawyer. They must also, to the extent possible, indicate those courses of conduct deemed improper and detail with maximal specificity the risks implicit in taking actions deemed undesirable. Recitation of "ideal" standards, and nothing else, gives no guidance to the "good" lawyer or law firm pressed at given times and for reasons of its own to adopt a compromising course but nonetheless desirous of avoiding action sufficiently undesirable as to call forth sanctions. 
and the ethics committees of the various bar associations, and particularly the American Bar Association, should begin to shape a flexible disqualification rule for law firms ${ }^{83}$ - a rule which would accommodate the interests of attorneys and clients. It is suggested that the necessary first step toward devising such a flexible rule is the establishment of formal procedures of discovery, notification and insulation within law firms. While such procedures would hardly eliminate the need for firm disqualification in all cases, they would provide the necessary precondition for greater flexibility in the application of any disqualification rule.

83. The holding in Bassett and companion determinations, see notes 6 and 14 supra, stand in sharp contrast to the Supreme Court's permissive allowance, for conflict of interest purposes, of the departmentalization of a partnership enterprise in many respects comparable to a law firm. In Blau v. Lehman, 368 U.S. 403 (1962), the Supreme Court refused to impute to all the members of a firm certain "inside" information concededly possessed by one of its partners, a director of a corporation in whose shares the firm had made a trading profit. At issue was the provision of $\S 16(\mathrm{~b})$ of the Securities Act which orders disgorgement of all "short swing" profits made by a defined class of corporate insiders, including directors. The Court allowed the Lehman Brothers firm to retain the profits it had made on the challenged transaction, requiring only a pro rata disgorgement of the "insider"-partner's share of the profit, with the understanding that he was not in any way to share in the profit retained by the firm. This was allowed on the strength of a showing satisfactory to the district court that the partner had not in fact passed on privileged information to the purchase committee of his firm. Thus, the Supreme Court allowed a partner - in possession of information of far more certain value than that generally possessed by an attorney with a client confidence - to shut himself off from his colleagues, and allowed those colleagues to discover on their own the profitable information which he possessed. Although the Supreme Court purported to rely on the statutory history of $\S 16(\mathrm{~b})$ as authority for its decision, that decision would hardly have been made had the Court regarded the closeness of the relationship of the firm partners such as to preclude any meaningful internal policing. Query whether there is a meaningful difference in closeness between the partners in Lehman Brothers and members of law firms. Moreover, one need not rejoice in the Blan decision [compare, The Supreme Court, 1961 Term, 76 HARv. L. REv. 54, 214-17 (1962), with 61 CoL. L. Rev. 926 (1961) ] to join in the thesis of this Note. Tax treatment of the "short swing" profit made by Lehman Brothers makes the Blau-type transaction one which is avoided whenever possible by the investment banks and by no means common to their operation. Interview, Partner — (New York Investment Bank), December, 1963. Thus, the case for permitting the compartmentalization of the Lehman Brothers partnership was in no real sense enhanced by the operative pressures on the banking industry. 